\title{
EFFECT OF SOME FEED ADDITIVES ON GROWTH PERFORMANCE, BLOOD COMPONENTS OF NILE TILAPIA
}

\author{
Mohammed A. Soliman", Hemat K.E Mahmoud, U.M. Abdel-Monem and M.S. Ayyat
}

Anim. Prod. Dept., Fac. Agric., Zagazig Univ., Egypt

\section{Received: 03/08/2017 ; Accepted: 24/08/2017}

\begin{abstract}
In a complete randomized design, Two hundred and ten fingerlings (weighing approximately $0.905 \pm 0.002 \mathrm{~g}$ all fish) were randomly distributed into 21 glass aquaria in 7 treatments (3 replicates per treatment). The first group was fed diet without any treatment (control), the second group was fed on diet supplemented with $\mathrm{SeO}_{2}(0.3 \mathrm{mg}$ selenium $/ \mathrm{kg}$ diet $)$ in fish diets, the third group was fed on diet supplemented with organic selenium supplemented; Sel-Plex ${ }^{\circledR}$ (0.3 mg selenium $/ \mathrm{kg}$ diet) in fish diets, the fourth group was fed the same diet and supplemented with zinc oxide (100 mg zinc/kg diet) in fish diets, the fifth group was fed on diet supplemented with EDTA zinc; $\mathrm{C}_{10} \mathrm{H}_{12} \mathrm{~N}_{2} \mathrm{O}_{8} \mathrm{ZnNa}_{2}$; (100 mg zinc/kg diet) in fish diets, the sixth group was fed on diet supplemented with clay $30 \mathrm{~g}$ bentonite $/ \mathrm{kg}$ feed (3\%) and the seventh group was fed on diet supplemented with nanoclay $30 \mathrm{~g}$ nano bentonite/ $\mathrm{kg}$ diet. There was no clear effect of dietary feed additives on the water quality in the all experimental groups. All water parameters were stable and within acceptable ranges. Fish groups fed diets supplemented with zinc oxide or selenium oxide recorded higher final live body weight and daily weight gain, then those fed diets supplemented with EDTA zinc, organic selenium and natural clay. Dietary feed additives reduced the mortality rate of fish. Fish group fed diet supplemented with EDTA zinc and nano-clay recorded the lower mortality rate. Fish groups fed diets supplemented with organic selenium and EDTA zinc recorded the best feed conversion ratio. No statistical differences were observed in fish body dry matter, crude protein, ether extract and ash as affected by dietary feed additives. Fish groups fed diets supplemented with EDTA zinc, selenium oxide, zinc oxide or organic selenium recorded the higher final margin and income from body gain. The best final margin was obtained in fish group fed diet supplemented with EDTA zinc.
\end{abstract}

Key words: Nile tilapia, selenium, zinc, clay, growth performance, feed utilization, margin.

\section{INTRODUCTION}

Fisheries and aquaculture remain important sources of food, nutrition, income and livelihoods for hundreds of millions of people around the world. In addition to the increase in production, other factors that have contributed to rising consumption include reductions in wastage, better utilization, improved distribution channels, and growing demand linked to population growth, rising incomes and urbanization. International trade has also played an important role in providing wider choices to consumers (FAO, 2016).

\footnotetext{
* Corresponding author: Tel. : +201122920191

E-mail address: M_A.soliman@yahoo.com
}

Micro-minerals such as zinc and selenium are essential to fish (Kaushik, 2002 ; Lall, 2002). A low or a high supply of dietary or aqueous trace minerals affects the associated biochemical and physiological responses in fish (Bury et al., 2003). Selenium an essential dietary nutrient plays an important role in normal functioning of the immune system, promoting a normal cellular immune response, and helping the body to resist viral infection (Rayman, 2000). The deficient or excessive dietary selenium levels can cause negative effects on growth, survival rate, peroxidative damage to cells (Lin and Shiau, 2005 ; Liu et al., 2010) and reduced host defense function (Sweetman et al., 2010; Wang et al., 
2013) in fish. Also, Zinc is an essential micromineral required for various metabolic pathways, including growth, protein synthesis, energy metabolism, and immunity of animals, including fish (Lin et al., 2013; Houng-Yung et al., 2014). Zinc serves as a functional cofactor for more than 200 metalloenzymes, such as superoxide dismutase, RNA polymerase, alkaline phosphatase, alcohol dehydrogenase, and carbonic anhydrase (Fountoulaki et al., 2010; Luo et al., 2011; Liang et al., 2012; Lin et al. 2013). The importance of zinc in the antioxidant protection has been also illustrated in many aquatic organisms (Trevisan et al., 2014 ; Huang et al., 2015). Natural clays are crystalline alumino-silicates characterized by their ably to exchange cations without major changes in structure. Natural clays can adsorb toxic products of digestion and decrease the accumulation of toxic substance in rabbit tissues, thus decreasing the incidence of internal disorders. Addition of natural clays in animal diets improves growth rate, feed conversion and increases return from body gain and final margin (Ayyat and Marai, 1997).

The present study aimed to investigate the effect of some safe feed additive on growth performance and blood parameters of Nile tilapia (Oreochromis niloticus).

\section{MATERIALS AND METHODS}

The present study was carried out at the Wet Laboratory of the Animal Production Department, Faculty of Agriculture, Zagazig University, Zagazig, Egypt. The experimental period lasted 84 days from May to August, 2016. In a complete randomized design, Two hundred and ten fingerlings (weighing approximately $0.905 \pm$ $0.002 \mathrm{~g}$ all fish were randomly distributed into 21 glass aquaria $\left(35 \times 70 \times 40 \mathrm{~cm}-0.074 \mathrm{~m}^{3}\right.$ of water) in 7 treatments ( 3 replicates per treatment). The first group was fed diet without any treatment (control), the second group was fed on diet supplemented with inorganic selenium; $\mathrm{SeO}_{2}$; supplemented $(0.3 \mathrm{mg}$ selenium $/ \mathrm{kg}$ diet $)$ in fish diets, the third group was fed on diet supplemented with organic selenium supplemented; YSC-100 USA ( $0.3 \mathrm{mg}$ selenium/ $\mathrm{kg}$ diet) in fish diets, the fourth group was fed the same diet and supplemented with inorganic zinc; zinc oxide;
(100 $\mathrm{mg}$ zinc/kg diet) in fish diets, the fifth group was fed on diet supplemented with EDTA zinc; $\mathrm{C}_{10} \mathrm{H}_{12} \mathrm{~N}_{2} \mathrm{O}_{8} \mathrm{ZnNa}_{2}$; supplemented (100 $\mathrm{mg}$ zinc/kg diet) in fish diets, the sixth group was fed on diet supplemented with clay $30 \mathrm{~g}$ bentonite/kg feed (3\%) and the seventh group was fed on diet supplemented with nano-clay 30 g nano bentonite/kg diet (The nano-clay was obtained from Egyptian Organization For Standardization And Quality Control, Egypt).

All fish groups were fed on basal pelleted diet (Table 1). Fish were fed at the rate of $5 \%$ of live body weight and it offered two times at 8.00 and 15.00 hours. The fish in each aquarium were weighed biweekly, and the feed weight was adjusted after each fish weighing. About 25\% of the water in the aquarium was daily replaced by aerated fresh water. Each aquarium was supplied with air pump to supply fish with oxygen.

The glass aquariums were supplied with well-aerated and dechlorinated tap water from storage tank. Air was compressed to each aquarium via air stones by air pumps during the experimental period. The diet remains and fish wastes of each aquarium were removed by siphoning using plastic tube before the second daily feeding to further analysis and minimize leaching. Every second day, each aquarium was partially cleaned including the fish feces and the water partially changed (about 50\%).

The proximate chemical on wet weight of whole-body composition including crude protein, crude fat, crude ash and moisture of body composition was determined using the standard procedures of AOAC (2005). At the end of the experimental period (12 weeks), fish were fasted for 12 hours immediately prior to blood sampling and five fish per glass aquaria were randomly chosen and anesthetized with $120 \mathrm{mg} / \mathrm{l}$ amino-benzoic acid (Sigma-Aldrich) before the drawing of blood. The blood was extracted from the caudal vein and divided in two sets of tubes. One set was left with no anticoagulant in order to clot at $4^{\circ} \mathrm{C}$ and centrifuged at $5000 \mathrm{rpm}$ for $5 \mathrm{~min}$ at room temperature. All blood parameters [Total protein, Albumin and globulin, Uric acid, Creatinine, Aspartate amino transferase (AST) and Alanine amino transferase (ALT). Red blood cells (RBC) and White blood cell (WBC), Hemoglobin (Hb)] were measured in privet labotatory. 
Table 1. Formulation and chemical composition of the basal experimental diet

\begin{tabular}{lc}
\hline Ingredient & Percent in basal experimental diet \\
\hline Fish meal & 17 \\
Soybean meal & 33 \\
Corn meal & 20 \\
Corn glutin & 6 \\
Wheat bran & 17 \\
Sunflower oil & 3 \\
Dicalciam phosphate & 2 \\
Vitamin mix ${ }^{1}$ & 0.5 \\
Mineral & ( \\
Carboxymethyl cellulose & 0.5 \\
Total & 1 \\
Proximate composition (\%) & 100 \\
Crude protein & \\
Eather extract & 32.62 \\
Crude fiber & 5.65 \\
Gross energy (Kcal/100g) & 4.53 \\
Price(L.E/Kg) & 4210.0 \\
\hline 1. Each Kg & 7.20 \\
\hline
\end{tabular}

1. Each one Kg of vitamin mixture contained: Vitam. A 72000IU, Vitam. B 6 mg, Vitam. B 12000 IU, Vitam. B6 $9 \mathrm{mg}$, B12 $0.06 \mathrm{mg}$, Vitam. E $60 \mathrm{mg}$, Vitam. k12 mg, Pantothonic acid $60 \mathrm{mg}$, Nicotinic acid $120 \mathrm{mg}$, Folic acid $6 \mathrm{mg}$, Biotin $0.3 \mathrm{mg}$ and Choline chlorids 3mg.

2. Each one $\mathrm{Kg}$ of mineral mixture contained: Zinc 1.3g, manganese 930mg, iron630mg, copper $105 \mathrm{mg}$, iodin10.5 mg, selenium2.1 mg.

Water quality control was measured biweekly analysis before replacing the water in the aquarium during the experimental period. All the water quality parameters were within the acceptable ranges for fish growth (Boyd, 1984). Water temperature was measured in each aquarium daily using a mercury thermometer of 0 to $100^{\circ} \mathrm{C}$ range. Dissolved oxygen was measured directly by using oxygen thermometer apparatus (XSI model 58, Yellow Spring Instrument Co., Yellow Springs, Ohio, USA). Ammonia $\left(\mathrm{NH}_{4}-\mathrm{N} \mathrm{mg} / \mathrm{l}\right)$, Nitrate $\left(\mathrm{NO}_{3}-\mathrm{N} \mathrm{mg} /\right.$ l), Nitrite $\left(\mathrm{NO}_{2}-\mathrm{Nmg} / \mathrm{l}\right)$ and $\mathrm{pH}$ were measured by using the Hach kit model HI 83205 (Multipurameter Bench Photometer, Hanna
Instruments, Romania). Continuous aeration was provided by an air blower.

Economic evaluation was calculated according to Ayyat (1991) as the following equation: Final margin (Profit) $=$ Income from body gain weight - feed cost. Relative margin $=$ Final margin $\times$ Survival rate. Other overhead costs were assumed constant. Price of one $\mathrm{kg}$ of diet was 7.20 LE (Egyptian pound $=0.056$ US\$) and price of selling of one kg live body weight of fish was 15.0 LE.

The data were statistically analyzed with SAS (2002) according to the following model

: $\mathrm{Y}_{\mathrm{ij}}=\mu+\mathrm{T}_{\mathrm{i}}+\mathrm{e}_{\mathrm{ij}}$, 
Where, $\mu$ is the overall mean, $\mathrm{T}$ is the fixed effect of treatments $(i=1 \ldots 7)$, and $e_{i j}$ is random error. Significant differences between treatments were tested with Duncan's multiple range test (Duncan, 1955).

\section{RESULTS AND DISCUSSION}

\section{Water Quality}

There was no clear effect of dietary feed additives on water quality in the all experimental groups. All water parameters were stable and within acceptable ranges (Boyd and Tucker, 1998). During the whole experimental period water-quality parameters i.e., averaged water temperature was $28.03^{\circ} \mathrm{C}$, dissolved oxygen was $7.52 \mathrm{mg} / \mathrm{l}$, total ammonia was $0.207 \mathrm{mg} / \mathrm{l}$, nitrite was $0.043 \mathrm{mg} / \mathrm{l}$ and $\mathrm{pH}$ was 7.3. Range of water quality parameters within the acceptable range required for normal growth of tilapia as mentioned by Boyd (1990).

\section{Growth Performance}

The average live body weight of Nile tilapia fingerlings at the beginning of the experiment was $0.90 \pm 0.002$ grams. The non significant differences between the experimental groups for initial live body weight indicated that the groups at the beginning of the experiment were homogenous (Table 2).

Final live body weight of fish increased by 67.60, 51.53, 68.50, 55.88, 43.14 and 37.92\% compared to the control, respectively, at fish group fed diet supplemented with selenium oxide, organic selenium, zinc oxide, EDTA zinc, clay and nano-clay, when compared with those fed diet without any supplementation (Table 2). Fish groups fed diets supplemented with zinc oxide or selenium oxide recorded higher final live body weight, followed by those fed diets supplemented with EDTA zinc, organic selenium and natural clay. Zinc is essential for normal growth of the farmed fish (Prasad, 1979 ; Stahl et al., 1989). Also, Ayyat et al. (2004) reported that live body weight of Nile tilapia increased significantly $(\mathrm{P}<0.001)$ as affected with zinc supplementation in the diets. Also, Zhoua et al. (2009) found that the final weight of carp fish increased significantly when fed selenomethionine compared with the control.
Also, Dlouha et al. (2008) reported that Dietary supplementation with selenium enriched alga Chlorella increased $(\mathrm{P}<0.05)$ body weight. The breast muscle Se concentration was increased (P $<0.05$ ) by selenium enriched alga Chlorella $(0.70 \mathrm{mg} / \mathrm{kg} \mathrm{DM} ; 0.36 \mathrm{mg} / \mathrm{kg} \mathrm{DM}$ in control) supplementation, but not $(\mathrm{P}>0.05)$ by SS $(0.49$ $\mathrm{mg} / \mathrm{kg} \mathrm{DM}$ ) supplementation. Also, Zhu et al. (2012) found the highest weight gain was obtained in fish fed diets with $1.60 \mathrm{mg}$ selenium/ $\mathrm{kg}$ diet, which was significant higher than the basal diet with $0.97 \mathrm{mg}$ selenium/ $\mathrm{kg}$ diet and did not differ significantly with the other treatments. Also, Naiel et al. (2012) found that fish growth indicated as live body weight, weight gain and specific growth rate (SGR) increased significantly and the maximum growth was obtained when fish fed diet containing $0.6 \mathrm{~g} \mathrm{OS} / \mathrm{Kg}$

Daily body weight gain of Nile tilapia fish affected significantly $(\mathrm{P}<0.001)$ with feed additives (Table 2). Average daily weight gain increased by 70.04, 53.07, 70.76, 57.76, 44.40 and $38.99 \%$ compared to the control, respectively, at fish group fed diet supplemented with selenium oxide, organic selenium, zinc oxide, EDTA zinc, clay and nano-clay, when compared with those fed diet without any supplementation (Table 2). Fish groups fed diets supplemented with zinc oxide or selenium oxide recorded higher average daily gain, then those fed diets supplemented with EDTA zinc, organic selenium and natural clay. The obtained results indicated that dietary zinc or selenium supplementation improved growth rate, these may be attributed to that zinc is involved in numerous aspects of cellular metabolism. It plays a role in immune function (Prasad, 1995 ; Solomons, 1998), protein synthesis (Prasad, 1995), wound healing (Heyneman, 1996), DNA synthesis and cell division (Prasad, 1995). Also, Selenium an essential dietary nutrient plays an important role in normal functioning of the immune system and helping the body to resist viral infection (Rayman, 2000). Eid and Ghonim (1994) reported that fish fed the lowest levels of supplemental zinc ( 0 and $5 \mathrm{mg}$ zinc/kg diet) had poor growth, while the level over $30 \mathrm{mg} / \mathrm{kg}$ diet showed markedly improved growth. Weight gain percent, feed efficiency, serum zinc and bone zinc concentrations indicated that the 
Table 2. Live body weight (g) and survival rate (\%) of Nile tilapia as affected by dietary feed additives at different experimental periods

\begin{tabular}{|c|c|c|c|c|}
\hline Treatment & $\begin{array}{l}\text { Initial weight } \\
\text { (g) }\end{array}$ & $\begin{array}{c}\text { Weight at } \\
12 \text { weeks (g) }\end{array}$ & $\begin{array}{c}\text { Daily gain at } \\
0-12 \text { weeks }\end{array}$ & $\begin{array}{c}\text { Relative growth at } \\
0-12 \text { weeks (g) }\end{array}$ \\
\hline Control & $0.90 \pm 0.02$ & $24.13 \pm 1.31^{\mathrm{d}}$ & $0.27 \pm 0.01^{\mathrm{d}}$ & $185.45 \pm 0.73^{\mathrm{C}}$ \\
\hline Inorganic selenium $0.3 \mathrm{mg} / \mathrm{kg}$ & $0.90 \pm 0.01$ & $40.44 \pm 1.69^{\mathrm{a}}$ & $0.47 \pm 0.00^{\mathrm{a}}$ & $191.22 \pm 0.37^{\mathrm{a}}$ \\
\hline Organic selenium $0.3 \mathrm{mg} / \mathrm{kg}$ & $0.90 \pm 0.01$ & $36.56 \pm 1.49^{\mathrm{bc}}$ & $0.42 \pm 0.01^{\mathrm{bc}}$ & $190.31 \pm 0.37^{\mathrm{ab}}$ \\
\hline Inorganic zinc 100 mg/kg & $0.90 \pm 0.02$ & $40.66 \pm 1.28^{\mathrm{a}}$ & $0.47 \pm 0.01^{\mathrm{a}}$ & $191.26 \pm 0.27^{\mathrm{a}}$ \\
\hline EDTA zinc 100 mg/kg & $0.90 \pm 0.01$ & $37.62 \pm 0.34^{\mathrm{ab}}$ & $0.43 \pm 0.00^{\mathrm{ab}}$ & $190.61 \pm 0.09^{\mathrm{ab}}$ \\
\hline Bentonite $30 \mathrm{~g} / \mathrm{kg}$ & $0.90 \pm 0.01$ & $34.54 \pm 1.29^{\mathrm{bc}}$ & $0.40 \pm 0.015^{\mathrm{bc}}$ & $189.76 \pm 0.35^{\mathrm{b}}$ \\
\hline Nano-clay 30 g / kg & $0.90 \pm 0.01$ & $33.28 \pm 0.27^{\mathrm{c}}$ & $0.38 \pm 0.03^{c}$ & $189.42 \pm 0.07^{\mathrm{b}}$ \\
\hline Significance & NS & $* * *$ & $* * *$ & $* * *$ \\
\hline
\end{tabular}

Means in the same column with different letters differ significantly $(\mathrm{P}<0.05)$.

*** $\mathrm{P}<0.001$ and NS $=$ Not significant.

minimum zinc requirement of fingerling Nile tilapia is $30 \mathrm{mg} \mathrm{Zn} / \mathrm{kg}$ diet. Also, Huang et al. (2015) found that the percent of weight gain of tilapia increased with increasing dietary zinc. Improved growth rate in fish fed diets supplemented with zinc may be attributed to that zinc is involved in numerous aspects of cellular metabolism. Zinc acts as cofactor to many enzymes and proteins, which are involved in protein synthesis, growth, the nervous system, gastrointestinal tract function, and in reproduction (Classen et al., 2011).

Relative growth rate of Nile tilapia fish affected significantly $(\mathrm{P}<0.001)$ with feed additives. Relative growth rate increased with supplemented of feed additives in fish diets (Table 2).

\section{Mortality Rate}

Dietary feed additives reduced the mortality rate of fish. Fish group fed diet supplemented with EDTA zinc and nano-clay recorded the lower mortality rate $(0.0 \%)$, while other fish groups recorded $3.33 \%$ mortality rate, but the control group recorded $6.67 \%$ mortality rate (Table 3).

Zinc and selenium plays a role in immune function (Prasad, 1995; Solomons, 1998; Lin and Shiau, 2005). Also, Ogino and Yang (1978) reported that the fish fed a diet low in zinc content (1 ppm) showed an extremely low growth rate and high mortality. A large number of the fish on the zinc-deficient diet were found to suffer from cataracts in the eyes and erosion of the fins and of the skin. On the other hand, Eid and Ghonim (1994) reported that fish fed the lowest levels of supplemental zinc ( 0 and 5 $\mathrm{mg} \mathrm{Zn} / \mathrm{kg}$ diet) had high mortality, while the levels over $30 \mathrm{mg} / \mathrm{kg}$ diet showed reduced mortality rate. The use of selenium as feed additives has important implications for health management in commercial aquaculture facilities.

\section{Feed Utilization}

Daily feed intake increased significantly $(\mathrm{P}<0.001)$ with feed additives supplementation at the all experimental periods (Table 3). Daily feed intake increased by 53.18, 30.25, 57.32, $26.75,36.31$ and $36.94 \%$ compared to the control, respectively in fish group fed diet supplemented with selenium oxide, organic selenium, zinc oxide, EDTA zinc, clay and nano-clay, when compared with those fed diet without any supplementation. Fish groups fed diets supplemented with zinc oxide or selenium oxide recorded higher daily feed intake. 
Table 3. Feed intake (g/day, feed conversion ratio ( $\mathrm{g}$ food/g gain) and mortality rate (\%) of Nile tilapia as affected by dietary feed additives at different experimental periods

\begin{tabular}{|c|c|c|c|}
\hline Treatment & $\begin{array}{l}\text { Daily feed intake } \\
\text { (g) }\end{array}$ & $\begin{array}{c}\text { Feed conversion } \\
\text { (g food/g gain) }\end{array}$ & $\begin{array}{c}\text { Mortality rate } \\
\text { (\%) }\end{array}$ \\
\hline Control & $0.31 \pm 0.07^{\mathrm{d}}$ & $1.13 \pm 0.04^{\mathrm{a}}$ & 6.67 \\
\hline Inorganic selenium $0.3 \mathrm{mg} / \mathrm{kg}$ & $0.48 \pm 0.04^{\mathrm{a}}$ & $1.02 \pm 0.03^{\mathrm{bc}}$ & 3.33 \\
\hline Organic selenium 0.3 mg/kg & $0.40 \pm 0.07^{\mathrm{bc}}$ & $0.96 \pm 0.04^{\text {cd }}$ & 3.33 \\
\hline Inorganic zinc 100 mg/kg & $0.49 \pm 0.09^{\mathrm{a}}$ & $1.04 \pm 0.02^{\mathrm{abc}}$ & 3.33 \\
\hline EDTA zinc 100 mg/kg & $0.39 \pm 0.06^{\mathrm{c}}$ & $0.91 \pm 0.01^{\mathrm{d}}$ & 0.00 \\
\hline Bentonite $30 \mathrm{~g} / \mathrm{kg}$ & $0.42 \pm 0.01^{\mathrm{b}}$ & $1.07 \pm 0.02^{\mathrm{ab}}$ & 3.33 \\
\hline Nano-clay30 g /kg & $0.43 \pm 0.03^{\mathrm{b}}$ & $1.11 \pm 0.01^{\mathrm{ab}}$ & 0.00 \\
\hline Significance & $* * *$ & $* * *$ & --- \\
\hline
\end{tabular}

Means in the same column with different letters differ significantly $(\mathrm{P}<0.05)$.

*** $\mathrm{P}<0.001$.

Feed conversion ratio significantly $(\mathrm{P}<0.001)$ affected with feed additives supplementation at the all experimental periods (Table 3). Feed conversion improved by $10.10,15.10,8.25$, 20.11, 5.97 and $2.02 \%$ compared to the control, respectively in fish group fed diet supplemented with selenium oxide, organic selenium, zinc oxide, EDTA zinc, clay and nano-clay, when compared with those fed diet without any supplementation. Fish groups fed diets supplemented with organic selenium and EDTA zinc recorded the best feed conversion ratio.

The same trend of the zinc supplementation was observed by Ayyat et al. (2004) who found that zinc supplementation in Nile tilapia fish diets improved feed conversion during the whole experimental period. Also, Zhao et al. (2011) showed that fish fed with a diet supplemented with $60 \mathrm{mg} \mathrm{kg}$ zinc/ $\mathrm{kg}$ diet from either $\mathrm{ZnSO}_{4}$ or ZnMet had a significantly greater protein efficiency ratio than those fed with the diets of $\leq 30 \mathrm{mg}$ zinc/ $/ \mathrm{kg}$ diet. $\mathrm{Li}$ and Huang (2016) reported that fish fed on a diet containing $31 \mathrm{mg} \mathrm{kg}^{-1}$ endogenous zinc showed the lowest feed utilization when compared with the control group.

Kucukbay et al. (2009) reported a linear increase in feed intake and weight gain and improvement in feed conversion ratio were found in sodium selenite or selenomethionine supplemented fish reared under crowding conditions. On the other hand, Zhu et al. (2012) documented that feed conversion ratio, protein efficiency ratio, protein productive value, apparent digestibility coefficients of dry matter and muscle composition were not significantly impacted by dietary selenium supplementation.

Kanyilmaz et al. (2014) found that the dietary zeolite treatments had a significant improved on feed conversion ratio of fish.

\section{Blood Components}

Blood hemoglobin content and RBC's counts increased significantly $(\mathrm{P}<0.001$ or 0.05$)$ as feed additives supplemented in fish diets, while WBC's and lymphocytes counts insignificant affected with experimental treatments (Table 4). Blood hemoglobin concentrate increased by 17.04, 12.49, 28.68, 20.56, 18.02 and 7.39\% compared to the control, respectively in fish group fed diet supplemented with selenium oxide, organic selenium, zinc oxide, EDTA zinc, clay and nano-clay, when compared with those fed diet without any supplementation (Table 4). Fish groups fed diets supplemented with zinc oxide or EDTA zinc recorded the higher blood hemoglobin concentration. Hemoglobin is an important chemical in red blood cells that carries oxygen, and performs different effect modulation and gas transport duties. Hemoglobin is the main 
Table 4. Hemoglobin, red blood cells, white blood cells and lymphocytes as affected by dietary feed additives on Nile tilapia fingerlings

\begin{tabular}{|c|c|c|c|c|}
\hline Treatment & $\begin{array}{c}\text { Hemoglobin } \\
(\mathrm{g} / \mathrm{dl})\end{array}$ & $\begin{array}{c}\text { RBCs counts X } \\
10^{6}(\text { cells } / \mu \mathrm{l})\end{array}$ & $\begin{array}{c}\text { WBCs counts } X \\
10^{3}(\text { cells } / \mu \mathrm{l}) \\
\end{array}$ & $\begin{array}{c}\text { Lymphocytes } \\
\text { cells/l }\end{array}$ \\
\hline Control & $5.51 \pm 0.17^{\mathrm{C}}$ & $1.39 \pm 0.05^{\mathrm{c}}$ & $19.96 \pm 0.41$ & $60.44 \pm 0.59$ \\
\hline Inorganic selenium $0.3 \mathrm{mg} / \mathrm{kg}$ & $6.44 \pm 0.09^{\mathrm{ab}}$ & $1.69 \pm 0.01^{\mathrm{ab}}$ & $19.82 \pm 0.46$ & $61.82 \pm 0.92$ \\
\hline Organic selenium $0.3 \mathrm{mg} / \mathrm{kg}$ & $6.19 \pm 0.44^{\mathrm{bc}}$ & $1.59 \pm 0.04^{\mathrm{b}}$ & $20.08 \pm 0.37$ & $59.83 \pm 0.34$ \\
\hline Inorganic zinc 100 mg/kg & $7.09 \pm 0.38^{\mathrm{a}}$ & $1.66 \pm 0.03^{\mathrm{ab}}$ & $20.02 \pm 0.35$ & $61.57 \pm 0.53$ \\
\hline EDTA zinc 100 mg/kg & $6.64 \pm 0.16^{\mathrm{ab}}$ & $1.63 \pm 0.05^{\mathrm{ab}}$ & $19.69 \pm 0.24$ & $60.03 \pm 0.71$ \\
\hline Bentonite $30 \mathrm{~g} / \mathrm{kg}$ & $6.50 \pm 0.24^{\mathrm{ab}}$ & $1.62 \pm 0.03^{\mathrm{ab}}$ & $19.77 \pm 0.22$ & $59.85 \pm 0.89$ \\
\hline Nano-clay30 g /kg & $5.91 \pm 0.16^{\mathrm{bc}}$ & $1.73 \pm 0.02^{\mathrm{a}}$ & $19.79 \pm 0.25$ & $60.96 \pm 0.70$ \\
\hline Significance & * & $* * *$ & NS & NS \\
\hline
\end{tabular}

Means in the same column with different letters differ significantly $(\mathrm{P}<0.05)$.

*** $\mathrm{P}<0.001, * \mathrm{P}<0.05$ and NS $=$ Not significant.

transport of oxygen and carbon dioxide in the blood. As with Hematocrit, it is an important determinant of anemia (decreased), dehydration (increased), polycythemia (increased), poor diet/nutrition, or possibly a malabsorption problem. The hemoglobin concentration of fishes is perhaps an index of their physiological activity. We may have in the fishes an illustration of how hemoglobin because of its function in respiration permits organisms to attain habits of definite survival value (Hall and Gray, 1929). Red blood cells count increased by $22.01,14.60,19.93,17.48,16.69$ and $24.46 \%$ compared to the control, respectively in fish group fed diet supplemented with selenium oxide, organic selenium, zinc oxide, EDTA zinc, clay and nano-clay, when compared with those fed diet without any supplementation. Fish groups fed diets supplemented with selenium oxide and nano-clay recorded the highest RBC's. Red blood cells main function is to carry oxygen to the tissues and to transfer carbon dioxide to the lungs. This process is possible through the RBC's containing hemoglobin which combines easily with oxygen and carbon dioxide. The application of haematological and serological techniques have proved valuable for fishery biologists in assessing the health of fish and monitoring stress responses either due to fluctuations in environmental condition or due to pollutants. In Nile tilapia, exposure to pollutants for long durations led to marked anemia and leukopenia (Rizkalla et al., 1997and Hussein et al. 2000).

Plasma total protein and its fractions, creatinine and uric acids significantly $(\mathrm{P}<0.001$ or 0.01) affected with feed additives supplementation in Nile tilapia feed (Table 5). Plasma total protein significantly $(\mathrm{P}<0.05)$ increased by 30.60, 23.29, 22.52, 15.24, 20.09 and $19.29 \%$ compared to the control, respectively in fish group fed diet supplemented with selenium oxide, organic selenium, zinc oxide, EDTA zinc, clay and nano-clay, when compared with those fed diet without any supplementation (Table 5). Fish groups fed diets supplemented with selenium oxide or organic selenium recorded the higher concentrate of blood total protein. Proteins are the most abundant compound in serum. Decreased levels may be due to poor nutrition or liver damage. Also, plasma albumin significantly $(\mathrm{P}<0.05)$ increased by $47.25,26.42,41.57,24.54,37.52$ and $34.56 \%$ compared to the control, respectively in fish group fed diet supplemented with selenium oxide, organic selenium, zinc oxide, EDTA zinc, clay and nano-clay, when compared with those fed diet without any supplementation. Fish groups fed diets supplemented with selenium oxide or zinc oxide recorded the higher concentrate of plasma albumin. The same figures for plasma globulin were 13.13, 20.05, 2.54, 5.47, 1.84 and 3.28 compared to the control; 
Table 5. Some plasma constituents as affected by dietary feed additives on Nile tilapia fingerlings

\begin{tabular}{|c|c|c|c|c|c|}
\hline Treatment & $\begin{array}{l}\text { Total protein } \\
\text { (g/dl) }\end{array}$ & $\begin{array}{c}\text { Albumin } \\
\text { (g/dl) }\end{array}$ & $\begin{array}{c}\text { Globulin } \\
\text { (g/dl) }\end{array}$ & $\begin{array}{c}\text { Creatinine } \\
\text { (mg/dl) }\end{array}$ & $\begin{array}{c}\text { Uric acid } \\
\text { (mg/dl) }\end{array}$ \\
\hline Control & $4.68 \pm 0.10^{\mathrm{d}}$ & $2.39 \pm 0.02^{\mathrm{e}}$ & $2.28 \pm 0.11^{\mathrm{C}}$ & $0.27 \pm 0.01^{\mathrm{a}}$ & $4.91 \pm 0.02^{\mathrm{a}}$ \\
\hline Inorganic selenium $0.3 \mathrm{mg} / \mathrm{kg}$ & $6.11 \pm 0.04^{\mathrm{a}}$ & $3.52 \pm 0.06^{\mathrm{a}}$ & $2.58 \pm 0.02^{\mathrm{ab}}$ & $0.23 \pm 0.01^{\mathrm{b}}$ & $4.41 \pm 0.13^{b}$ \\
\hline Organic selenium $0.3 \mathrm{mg} / \mathrm{kg}$ & $5.77 \pm 0.09^{\mathrm{b}}$ & $3.02 \pm 0.05^{\mathrm{d}}$ & $2.74 \pm 0.07^{\mathrm{a}}$ & $0.23 \pm 0.01^{\mathrm{b}}$ & $4.36 \pm 0.09^{\mathrm{b}}$ \\
\hline Inorganic zinc 100 mg/kg & $5.73 \pm 0.06^{\mathrm{b}}$ & $3.39 \pm 0.01^{\mathrm{b}}$ & $2.34 \pm 0.05^{\mathrm{c}}$ & $0.23 \pm 0.05^{\mathrm{b}}$ & $4.30 \pm 0.04^{\mathrm{b}}$ \\
\hline EDTA zinc 100 mg/kg & $5.39 \pm 0.09^{c}$ & $2.98 \pm 0.03^{\mathrm{d}}$ & $2.40 \pm 0.06^{\mathrm{bc}}$ & $0.24 \pm 0.05^{\mathrm{b}}$ & $4.21 \pm 0.06^{\mathrm{b}}$ \\
\hline Bentonite $30 \mathrm{~g} / \mathrm{kg}$ & $5.62 \pm 0.01^{\mathrm{bc}}$ & $3.29 \pm 0.02^{\mathrm{bc}}$ & $2.32 \pm 0.02^{\mathrm{c}}$ & $0.23 \pm 0.03^{\mathrm{b}}$ & $4.45 \pm 0.06^{\mathrm{b}}$ \\
\hline Nano-clay 30 g / kg & $5.58 \pm 0.03^{\mathrm{bc}}$ & $3.22 \pm 0.01^{\mathrm{c}}$ & $2.35 \pm 0.02^{\mathrm{c}}$ & $0.22 \pm 0.05^{\mathrm{b}}$ & $4.22 \pm 0.03^{\mathrm{b}}$ \\
\hline Significance & $* * *$ & $* * *$ & $* *$ & ** & $* * *$ \\
\hline
\end{tabular}

Means in the same column with different letters differ significantly $(\mathrm{P}<0.05)$.

*** $\mathrm{P}<0.001$ and $* * \mathrm{P}<0.01$.

respectively. Albumin is the major constituent of serum protein. It is manufactured by the liver from the amino acids taken through the diet. It helps in osmotic pressure regulation, nutrient transport and waste removal. Lower levels are seen in poor diets, infection, liver damage or inadequate iron intake. On the other hand, the plasma concentrations of creatinine and uric acids decreased significantly as affected with dietary feed additives. Plasma creatinine significantly $(\mathrm{P}<0.05)$ decreased by 12.55 , 15.30, 14.76, 9.96, 12.18 and $16.97 \%$, compared to the control respectively in fish group fed diet supplemented with selenium oxide, organic selenium, zinc oxide, EDTA zinc, clay and nano-clay, when compared with those fed diet without any supplementation (Table 5). The same trend was observed in uric acid concentration. The decreased values were 10.22, $11.15,12.38,14.17,9.42$ and $14.06 \%$ compared to the control, respectively. Creatinine is the waste product of muscle metabolism. Its level is a reflection of the bodies muscle mass. Elevated levels are sometimes seen in kidney disease due to the kidneys job of excreting creatinine, muscle degeneration, and some drugs involved in impairment of kidney function.

Plasma transaminase enzymes (AST and ALT) and total lipids concentrations significantly $(\mathrm{P}<0.05)$ decreased as affected with dietary feed additives, while glucose concentration significantly $(\mathrm{P}<0.01)$ increased (Table 6). AST and ALT are reasonably sensitive indicators of liver damage or injury from different types of diseases or conditions, and collectively they are termed liver tests or liver blood tests. However, it must be emphasized that higher-than-normal levels of these liver enzymes should not be automatically equated with liver disease. They may mean liver problems or they may not. Low levels of AST are normally found in the blood. The amount of AST in the blood is directly related to the extent of the tissue damage.

Plasma glucose significantly $(\mathrm{P}<0.05)$ increased by $9.32,7.57,8.04,7.82,9.44$ and $7.00 \%$ compared to the control, respectively in fish group fed diet supplemented with selenium oxide, organic selenium, zinc oxide, EDTA zinc, clay and nano-clay, when compared with those fed diet without any supplementation (Table 6). Fish groups fed diets supplemented with selenium oxide or zinc oxide recorded higher concentrate of plasma albumin. On the other hand, plasma total lipids significantly $(\mathrm{P}<0.05)$ decreased by 2.96, 3.27, 3.74, 3.23, 2.96 and $4.39 \%$ compared to the control, respectively in fish group fed diet supplemented with selenium oxide, organic selenium, zinc oxide, EDTA zinc, clay and nano-clay, when compared with those fed diet without any supplementation. 
Table 6. Some plasma constituents as affected by dietary feed additives on Nile tilapia fingerlings

\begin{tabular}{|c|c|c|c|c|}
\hline Treatment & $\begin{array}{c}\text { AST } \\
\text { (UI//) }\end{array}$ & $\begin{array}{c}\text { ALT } \\
\text { (IU/I) }\end{array}$ & $\begin{array}{l}\text { Glucose } \\
\text { (mg/dl) }\end{array}$ & $\begin{array}{l}\text { Total lipids } \\
\text { (mg/dl) }\end{array}$ \\
\hline Control & $44.38 \pm 0.49^{\mathrm{a}}$ & $39.02 \pm 0.46^{\mathrm{a}}$ & $135.20 \pm 0.72^{b}$ & $129.12 \pm 1.47^{\mathrm{a}}$ \\
\hline Inorganic selenium $0.3 \mathrm{mg} / \mathrm{kg}$ & $40.38 \pm 0.69^{b}$ & $34.73 \pm 0.77^{\mathrm{b}}$ & $147.80 \pm 2.20 \mathrm{a}$ & $125.29 \pm 0.37^{\mathrm{b}}$ \\
\hline Organic selenium $0.3 \mathrm{mg} / \mathrm{kg}$ & $41.05 \pm 0.86^{\mathrm{b}}$ & $34.29 \pm 0.61^{\mathrm{b}}$ & $145.43 \pm 1.58^{\mathrm{a}}$ & $124.90 \pm 1.28^{\mathrm{b}}$ \\
\hline Inorganic zinc 100 mg/kg & $41.48 \pm 0.72^{\mathrm{b}}$ & $34.60 \pm 0.90^{\mathrm{b}}$ & $146.06 \pm 0.75^{\mathrm{a}}$ & $124.29 \pm 0.21^{\mathrm{b}}$ \\
\hline EDTA zinc 100 mg/kg & $41.22 \pm 0.52^{\mathrm{b}}$ & $34.30 \pm 1.063^{\mathrm{b}}$ & $145.76 \pm 1.51^{\mathrm{a}}$ & $124.95 \pm 0.36^{\mathrm{b}}$ \\
\hline Bentonite $30 \mathrm{~g} / \mathrm{kg}$ & $41.32 \pm 0.59^{\mathrm{b}}$ & $34.80 \pm 1.40^{\mathrm{b}}$ & $147.96 \pm 2.19^{\mathrm{a}}$ & $125.30 \pm 1.04^{\mathrm{b}}$ \\
\hline Nano-clay 30 g / kg & $42.29 \pm 0.83^{\mathrm{ab}}$ & $36.15 \pm 0.70^{\mathrm{b}}$ & $144.66 \pm 2.26^{\mathrm{a}}$ & $123.45 \pm 0.61^{\mathrm{b}}$ \\
\hline Significance & * & $*$ & $* *$ & $*$ \\
\hline
\end{tabular}

Means in the same column with different letters differ significantly $(\mathrm{P}<0.05)$.

** $\mathrm{P}<0.01$ and $* \mathrm{P}<0.05$.

Ayyat et al. (2004) reported that serum total protein, albumin, creatinine and AST significantly increased with increasing zinc level in fish diet, while ALT significantly decreased. Abdel-Tawwab et al. (2007) revealed the increases in total lipid, total protein, albumin and globulin levels, AST and ALT in blood of African catfish as increasing dietary selenium levels. Also, Khalafalla et al. (2011) found that increasing dietary selenium level caused significant increases in total protein, albumin and globulin compared to the control diet.

\section{Body Composition}

No statistical differences were observed in fish body dry moisture, crude protein, ether extract and ash as affected by dietary feed additives (Table 7). Ether extract percentages of the flesh insignificantly decreased as affected by dietary feed additives. The results of Zhao et al. (2011) showed that the composition of tilapia carcass was also found to be influenced by various levels of dietary zinc. Ayyat et al. (2004) reported that fish body composition did not affected significantly with dietary zinc supplementation.

\section{Profit Analysis}

Feed cost, income from body gain and final margin clearly increased with dietary feed additives supplementation in Nile tilapia fish
(Table 8). Feed cost increased by 53.16, 30.00, $57.37,26.84,36.26$ and $36.84 \%$ compared to the control, respectively in fish group fed diet supplemented with selenium oxide, organic selenium, zinc oxide, EDTA zinc, clay and nano-clay, when compared with those fed diet without any supplementation. Also, income from body gain increased by 70.20, 53.01, 70.77, 57.88, 44.41 and $38.97 \%$, respectively in fish group fed diet supplemented with selenium oxide, organic selenium, zinc oxide, EDTA zinc, clay and nano-clay. The same figures for final margin were 90.57, 80.50, 86.79, 94.97, 54.09 and $41.51 \%$, respectively (Table 8 ). Fish groups fed diets supplemented with EDTA zinc, selenium oxide, zinc oxide or organic selenium recorded higher final margin and income from body gain. The best final margin was obtained in fish group fed diet supplemented with EDTA zinc.

\section{Conclusion}

The results from the present study indicated that growth performance, feed utilization, feed cost, income from body gain and final margin showed significant improvement compared to the control group with dietary feed additives supplementation to feed of Nile tilapia fish. The present study recommends using safe feed additives in Nile tilapia fish production. 
Table 7. Proximate chemical analysis on wet weight of whole-body of Nile tilapia as affected by dietary feed additives on Nile tilapia fingerlings

\begin{tabular}{|c|c|c|c|c|}
\hline Treatment & Moisture (\%) & Crude protein (\%) & Ether extract (\%) & Ash (\%) \\
\hline Control & $74.15 \pm 0.14$ & $17.91 \pm 0.20$ & $6.91 \pm 0.52$ & $3.92 \pm 0.33$ \\
\hline Inorganic selenium $0.3 \mathrm{mg} / \mathrm{kg}$ & $73.03 \pm 0.25$ & $17.24 \pm 0.01$ & $6.74 \pm 1.20$ & $3.24 \pm 1.02$ \\
\hline Organic selenium $0.3 \mathrm{mg} / \mathrm{kg}$ & $74.24 \pm 0.25$ & $17.28 \pm 0.20$ & $4.99 \pm 1.24$ & $3.70 \pm 0.22$ \\
\hline Inorganic zinc 100 mg / kg & $72.79 \pm 0.27$ & $16.86 \pm 0.30$ & $5.50 \pm 0.50$ & $3.82 \pm 1.13$ \\
\hline EDTA zinc 100 mg / kg & $73.44 \pm 0.23$ & $17.87 \pm 0.24$ & $5.98 \pm 1.03$ & $3.62 \pm 1.23$ \\
\hline Bentonite $30 \mathrm{~g} / \mathrm{kg}$ & $70.12 \pm 0.20$ & $17.07 \pm 0.32$ & $6.66 \pm 1.01$ & $3.73 \pm 1.13$ \\
\hline Nano-clay 30 g /kg & $74.94 \pm 0.24$ & $17.46 \pm 0.01$ & $5.70 \pm 1.01$ & $3.83 \pm 1.23$ \\
\hline Significance & NS & NS & NS & NS \\
\hline
\end{tabular}

NS= Not significant.

Table 8. Economic visibility of Nile tilapia fish as affected by dietary feed additives

\begin{tabular}{|c|c|c|c|c|c|}
\hline Treatment & $\begin{array}{l}\text { Total feed } \\
\text { intake (g) }\end{array}$ & $\begin{array}{l}\text { Feed cost } \\
\text { (LE)/fish }\end{array}$ & $\begin{array}{c}\text { Total } \\
\text { gain }(g)\end{array}$ & $\begin{array}{l}\text { Income from } \\
\text { gain (LE)/fish }\end{array}$ & $\begin{array}{l}\text { Final margin } \\
\text { (LE)/fish }\end{array}$ \\
\hline Control & 26.37 & 0.19 & 23.26 & 0.34 & 0.15 \\
\hline Inorganic selenium $0.3 \mathrm{mg} / \mathrm{kg}$ & 40.40 & 0.29 & 39.56 & 0.59 & 0.30 \\
\hline Organic selenium 0.3 mg/kg & 34.35 & 0.24 & 35.61 & 0.53 & 0.28 \\
\hline Inorganic zinc $100 \mathrm{mg} / \mathrm{kg}$ & 41.49 & 0.29 & 39.73 & 0.59 & 0.29 \\
\hline EDTA zinc 100 mg/kg & 33.43 & 0.24 & 36.70 & 0.55 & 0.31 \\
\hline Bentonite $30 \mathrm{~g} / \mathrm{kg}$ & 35.95 & 0.25 & 33.60 & 0.50 & 0.24 \\
\hline Nano-clay 30 g / kg & 36.12 & 0.26 & 32.34 & 0.48 & 0.22 \\
\hline
\end{tabular}

\section{REFERENCES}

Abdel-Tawwab, M., M.A.A. Mousa and F.E. Abbass (2007). Growth performance and physiological response of African catfish, Clarias gariepinus (B.) fed organic selenium prior to the exposure to environmental copper toxicity. Aquac., 272 (1-4): 335-345.

AOAC (2005). Official Methods of Analysis Chemists. $18^{\text {th }}$ Ed. Edited by Dr. William Horwitz and Dr. George W. Latimer, Jr., AOAC Int., Washington DC, USA.
Ayyat M.S. (1991). Growth and carcass production of growing rabbits as affected by dietary energy level. Zagazig J. Agric. Res., 18 (1): 109-122.

Ayyat, M.S. and I.F.M. Marai (1997). Use of natural clays in animal production. Proc. Int. Conf. Anim., Poult. and Rabbit Prod. and Health, Egypt. Int. Cent. Agric., Cairo, Egypt, 91-111.

Ayyat, M.S., F.S. Abbas, S.M. Sharaf and H.I. El-Marakby (2004). Growth performance, feed utilization and blood components of Nile tilapia Oreochromis nilotics as affected 
by dietary protein source and zinc supplementation. J. Egypt. Academic Soc. Environ. Develop., 5 (1): 1-15.

Boyd, C.E. (1984). Water Quality in Warm water Fishponds. Auburn Univ. Agric. Experim. Station, Auburn, Alabama, USA.

Boyd, C.E. (1990). Water Quality in Ponds for Aquaculture. Bermingham Publishing Co., Bermingham, Alabama, USA. Chaturvedi, V.B., K.S.

Boyd, C.E. and C.E. Tucker (1998). Ecology of aquaculture ponds.in pond Aquaculture water quality Management. Springer US.P8-86.

Bury, N.R., P.A. Walker and C.N. Glover (2003). Nutritive metal uptake in teleost fish. J. Experim. Biol., 206: 11-23.

Classen, H.G., U. Gröber, D. Löw, J. Schmidt and H. Stracke (2011). Zinc deficiency: Symptoms, causes, diagnosis and therapy. Medizinische Monatsschrift Fur Pharmazeuten, 34: 87-95.

Dlouha, G., S. Ševčikova, A. Dokoupilova, L. Zita, J. Heindl and M. Skřivan (2008). Effect of dietary selenium sources on growth performance, breast muscle selenium, glutathione peroxidase activity and oxidative stability in broilers Czech J. Anim. Sci., 53 (6): 265-269

Duncan, D.B. (1955). Multiple Range and Multiple F-test. Biometrics, 11: 1-42.

Eid, A.E. and S.I. Ghonim (1994). Dietary zinc requirement of fingerling Oreochromis niloticus. Aquac., 119 (2-3): 259-264.

FAO (2016). The State of World Fisheries and Aquaculture 2016. Contributing to food security and nutrition for all. Rome. 200.

Fountoulaki, E., H. Morgane, G. Rigos, V. Antigoni, E. Mente, J. Sweetman and I. Nengas (2010). Evaluation of zinc supplementation in European sea bass, Dicentrarchus labrax, juvenile diets. Aquac. Res., 41: 208-216.

Hall, F.G. and I.E. Gray (1929). The hemoglobin concentration of the blood of marine fishes. J. Biol. Chem., 81: 589-594.
Heyneman, C.A. (1996). Zinc deficiency and taste disorders. Ann. Pharmacother., 30: 186187.

Houng-Yung, C., C. Yu-Chun, H. Li-Chi and C. Meng-Hsien (2014). Dietary zinc requirements of juvenile grouper, Epinephelus malabaricus. Aquaculture, 432: 360-364.

Huang, F., M. Jiang, H. Wen, H. Wu, W. Liu, J. Tian and C. Yang (2015). Dietary zinc requirement of adult Nile tilapia (Oreochromis niloticus) fed semi-purified diets, and effects on tissue mineral composition and antioxidant responses. Aquac., 439: 53-59.

Hussein, S.Y., I.A. Mekkawy, Z.Z. Moktar and M. Mubarak (2000). Protective effect of Nigella sativa seed against aflatoxicosis in Oreochromis niloticus. Proceeding of Conference Mycotoxins and Dioxins and the Environ., Bydgoszcz, Poland, 109 - 130.

Kanyilmaz, M., N. Tekelioglu, H. Sevgili, R. Uysal and A. Aksoy (2014). Effects of dietary zeolite (clinoptilolite) levels on growth performance, feed utilization and waste excretions by gilthead sea bream juveniles (Sparus aurata). Anim. Feed Sci. and Technol., 200: 66-75.

Kaushik, S. (2002). Mineral nutrition. In: Nutrition and Feeding of Fish and Crustaceans, Guillaume, J., Kaushik, S., Bergot, P., Metailler, R., Editors. Chichester, UK: Springer-Praxis Publishing Ltd, 169181.

Khalafalla, M.M.E., N.M. Eweedah, M.F.I. Salem and A.E. Sallam (2011). Effects of different levels of selenium supplementation on growth performance, feed utilization, spawning performance and reproduction of the Nile tilapia (Oreochromis niloticus). Proceedings of the $4^{\text {th }}$ Global Fisheries and Aquac. Res. Conf., the Egypt. Int. Cent. Agric., Giza, Egypt, 75-91.

Kucukbay, F.Z., H. Yazlak, I. Karaca, N. Sahn, M. Tuzcu, M.N. Cakmak and K. Sahn (2009). The effects of dietary organic or inorganic selenium in rainbow trout (Oncorhynchus mykiss) under crowding conditions. Aquac. Nut., 15 (6): 569-576. 
Lall, S.P. (2002). The Minerals. In: Fish Nutrition. John, E.H., Ronald, W.H., Editors. ( $3^{\text {rd }}$ Ed.). San Diego, Acad. Press, 259-308.

Li, M.R. and C.H. Huang (2016). Effect of dietary zinc level on growth, enzyme activity and body trace elements of hybrid tilapia, Oreochromis niloticus $\times$ O. aureus, fed soya bean meal-based diets. Aquac. Nut., 22: 1320-1327.

Liang, J.J., H.J. Yang, Y.J. Liu, L.X. Tian and G.Y. Liang (2012). Dietary zinc requirement of juvenile grass carp, Ctenopharyngodon idella, based on growth and mineralization. Aquac. Nut., 18: 380-387.

Lin, S., X. Lin, Y. Yang, F. Li and L. Luo (2013). Comparison of chelated zinc and zinc sulfate as zinc sources for growth and immune response of shrimp, Litopenaeus vannamei. Aquac., 406-407: 79-84.

Lin, Y.H. and S.Y. Shiau (2005). Dietary selenium requirements of juvenile grouper, Epinephelus malabaricus. Aquac., 250 (1-2): 356-363.

Liu, K., X.J. Wang, Q. Ai, K. Mai and W. Zhang (2010). Dietary selenium requirement for juvenile cobia, Rachycentron canadum L. Aquac. Res., 41 (10): 594-601.

Luo, Z., X.Y. Tan, J.L. Zheng, Q.L. Chen and C.X. Liu (2011). Quantitative dietary zinc requirement of juvenile yellow catfish Pelteobagrus fulvidraco, and effects on hepatic intermediary metabolism and antioxidant responses. Aquac., 319: 150-155.

Naiel, M.A.E., A.E. Nasr and M.H. Ahmed (2012). Influnce of organic selenium and stocking density on perfopmance of Nile tilapia (Oreochromis niloticus). Zagazig J. Agric. Res., 39 (1)

Ogino, C. and G.Y. Yang (1978). Requirement of rainbow trout for dietary zinc. Bulletin of the Japanese Society of Scientific Fisheries, 44: 1015-1018.

Prasad, A.S. (1979). Clinical, biochemical, and pharmacological role of zinc. Ann. Rev. Pharmacol. and Toxicol., 20: 393-426.

Prasad, A.S. (1995). Zinc: an overview. Nut., 11: $93-99$.
Rayman, M.P. (2000). The importance of selenium to human health. Lancet, 356 : 233-241.

Rizkalla, E.H., M.H. Zahra, A. Deab and M.F. Farag (1997). Hematological responsiveness of Oreochromis aureus to dietary aflatoxins contamination and the role of selenium and vitamin E. Alex. J. Vet. Sci., 13(4): 423-438.

SAS (2002). SAS Institute Inc., Cary, NC, USA. NOTE: SAS Proprietary Software Version 9.00 (TS MO).

Solomons, N.W. (1998). Mild human zinc deficiency produces an imbalance between cell-mediated and humoral immunity. Nut. Rev., 56: 27-28.

Stahl, J.L., M.E. Cook, M.L. Sunde and J.L. Greger (1989). Enhanced humoral immunity in progeny chicks fed practical diets supplemented with zinc. Appl. Agric. Res., 4: 86-89.

Sweetman, J.W., S. Torrecillas, A. Dimitroglou, S. Rider, S.J. Davies and M.S. Izquierdo (2010). Enhancing the natural defences and barrier protection of aquaculture species. Aquac. Res., 41 (3): 345-355.

Trevisan, R., S. Flesch, J.J. Mattos, M.R. Milani, A.C.D. Bainy and A.L. Dafre (2014). Zinc causes acute impairment of glutathione metabolism followed by coordinated antioxidant defenses amplification in gills of brown mussels Perna perna. Comp. Biochem. and Physiol. Part C. 159: 22-30.

Wang, K., C.Z. Peng, J.L. Huang, Y.D. Huang, M.C. Jin and Y. Geng (2013). The pathology of selenium deficiency in Cyprinus carpio L. J. Fish Dis., 36 (7): 609-615.

Zhao, H.X., J.M. Cao, X.H. Liu, X. Zhu, S.C. Chen, H.B. Lan and A.L. Wang (2011). Effect of supplemental dietary zinc sources on the growth and carbohydrate utilization of tilapia Smith 1840, Oreochromis niloticus $\times$ Oreochromis aureus. Aquac. Nut., 17: 64.72.

Zhoua, X., Y. Wangb, Q. Gub and W. Lia (2009). Effects of different dietary selenium sources (selenium nanoparticle and selenomethionine) on growth performance, muscle composition and glutathione peroxidase enzyme activity of crucian carp (Carassius auratus gibelio). Aquac., 291:7881. 
Zhu, Y., Y. Chen, Y. Liu, H. Yang, G. Liang and L. Tian (2012). Effect of dietary selenium level on growth performance, body composition and hepatic glutathione peroxidase activities of largemouth bass Micropterus salmoide. Aquac. Res., 43 (11): 1660-1668.

\section{تأثيــر بعــ إضــــافــات الأعـــلاف علـى أداء النمو، ومكونـات الام في أســـاك البلطـي النيلـي \\ محمد أحمد سليمان ـ همت كمال الدين محمود ـ أسامة محمد عبد المنعم ـ محمد صلاح الدين محمد عياط

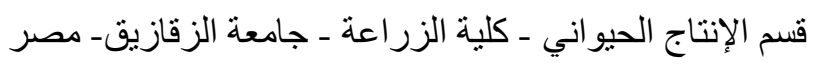

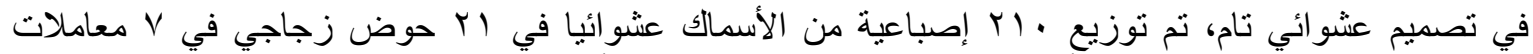

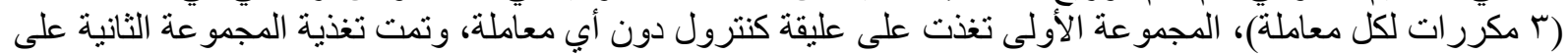

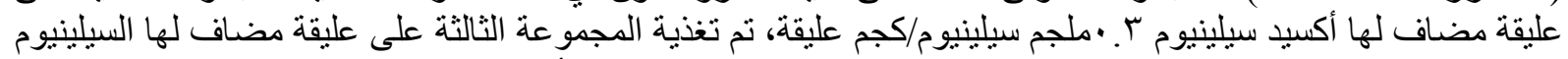

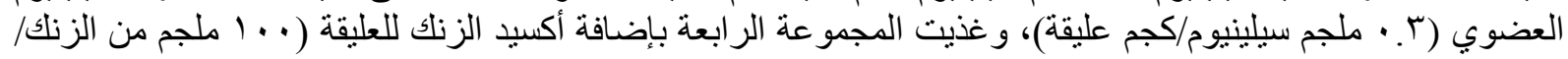

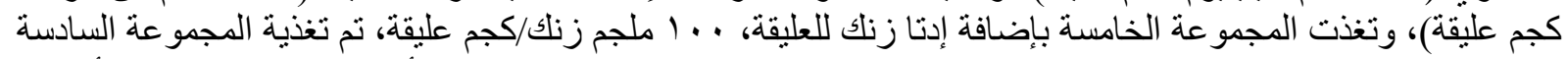

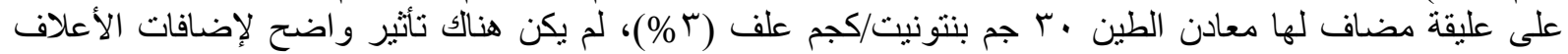

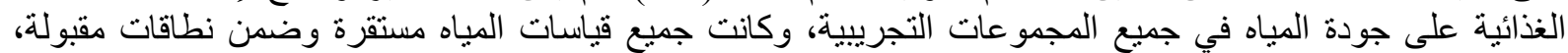

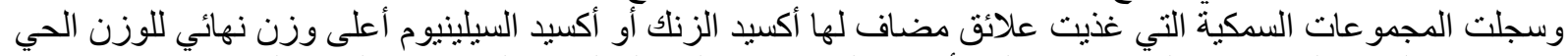

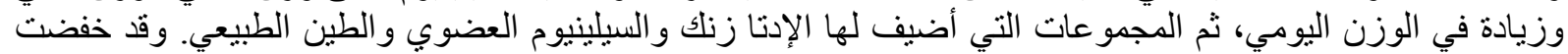

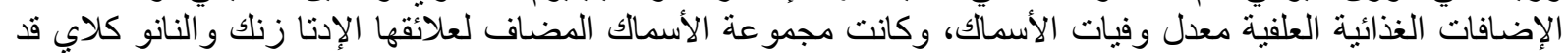

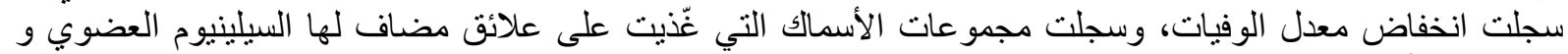

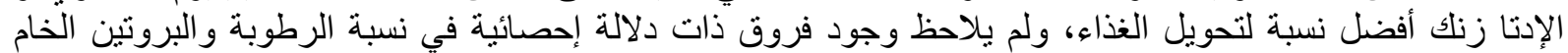

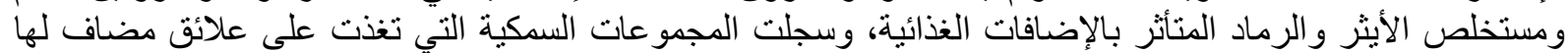

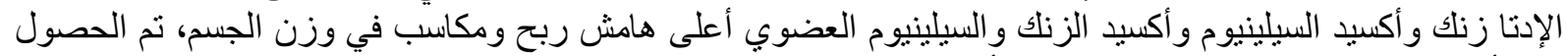

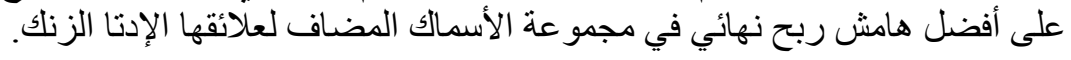

